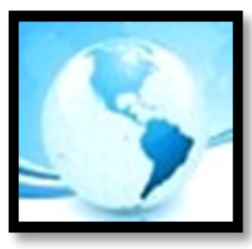

\author{
January 2019, VOLUME 7, ISSUE 1, 37 - 56 \\ E-ISSN NO: $2289-4489$
}

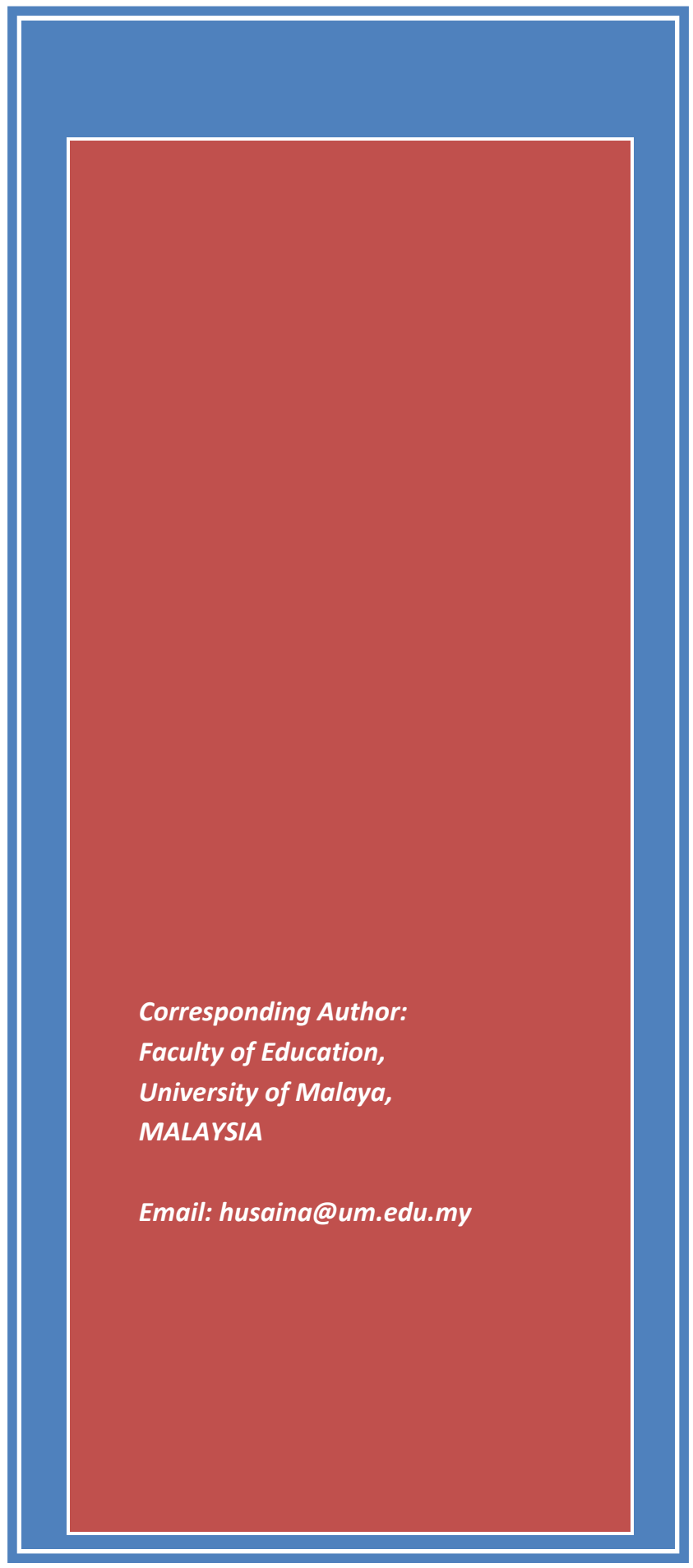

\title{
SCHOOL LEVEL RESOURCES AND STUDENTS' PERFORMANCE IN MALAYSIAN NATIONAL TYPE CHINESE SCHOOLS
}

Husaina Banu Kenayathulla (PhD), Hee Fui Ling, Ahmad Zabidi Abdul Razak (PhD) \& Ghazali Darusalam (PhD)

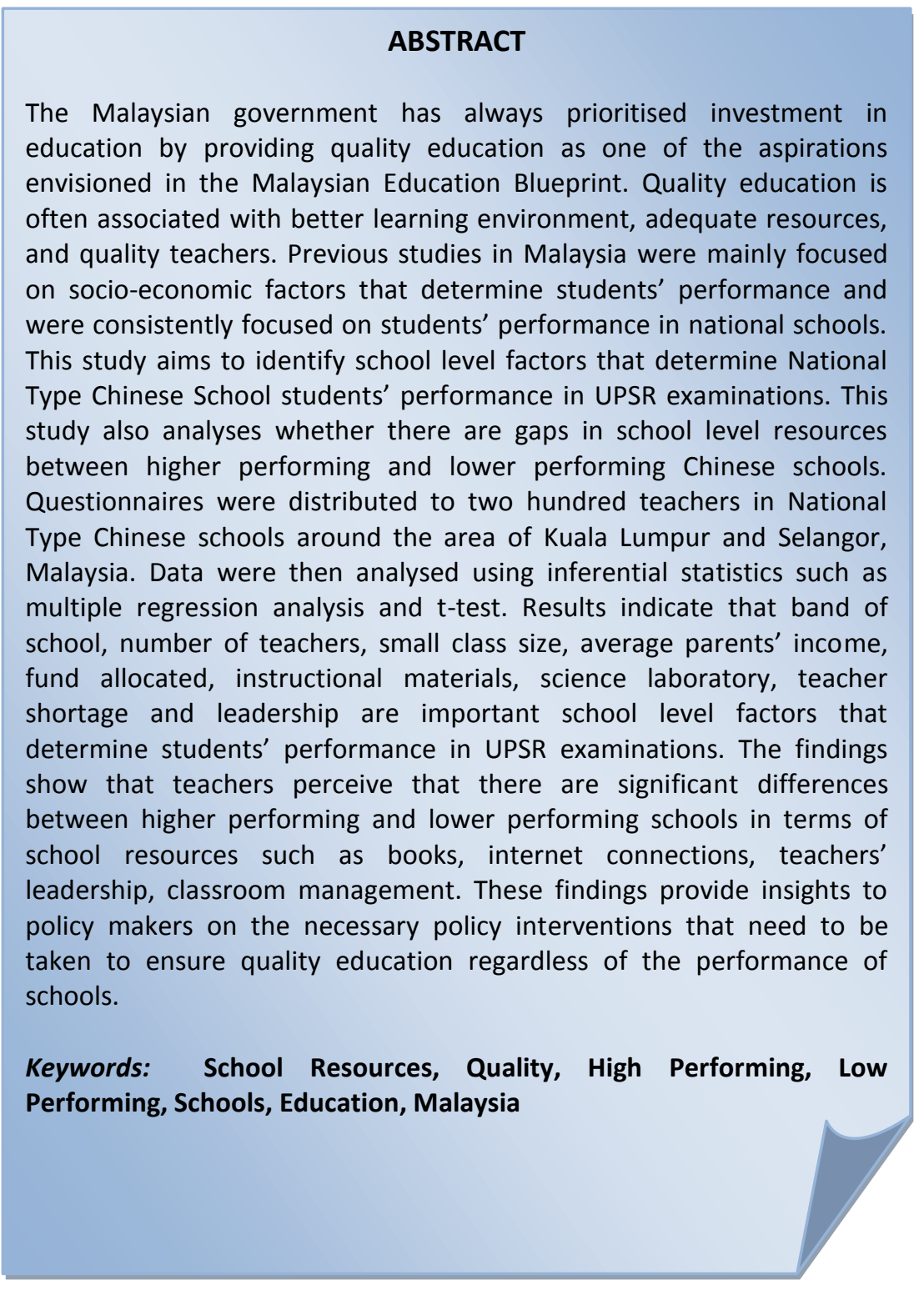




\section{MALAYSIAN ONLINE JOURNAL OF EDUCATIONAL MANAGEMENT (MOJEM)}

\section{INTRODUCTION}

The Malaysian government has always prioritised investment in education by providing quality education as one of the aspirations envisioned in the Malaysian Education Blueprint. Quality education is often associated with better learning environment, adequate resources, and quality teachers. The Malaysia Education Blueprint (2013-2025) aims to provide a long term policy direction in Malaysia Education System (Ministry of Education, 2012). The plan aims to provide equal and quality education opportunities for all students in Malaysia regardless their family backgrounds and socioeconomic status. The Malaysian government has identified several strategies and action plans to ensure successful implementation of the Blueprint. One of the strategies used by the government in implementing the plan is through the National Key Results Area (NKRA) which was targeted to improve students' performance significantly in their learning. It focused on efforts to increase the percentage of young citizens who will benefit from pre-school to secondary level education. Besides that, the NKRA is related to other sub strategies to improve educational facilities and infrastructures in school. The sub strategies are also auxiliaries to increase students' participation rates and to reduce students' dropout rates. The sub strategies strongly focus on improving equity in education. It narrows the education gaps of rural and urban school. To improve the quality of schools, the strategy used must ensure that physical facilities, infrastructure, headmasters, teachers, management staff, adequate teaching and learning materials and others are adequate in all schools or educational institutions (Ahmad, 2012).

At the primary level, there are two types of schools: National Schools and National Type Schools. The medium of instruction in National Schools is the Malay Language whereas National Type Schools have been using Tamil and Chinese as a medium of instruction. Whilst Malay is the national language of Malaysia, the use of Chinese and Tamil languages reflects the presence of three distinct racial and ethnic groups, Malays, Chinese and Indians (Joseph, 2008). The majority of Chinese and Tamils attend National Type Schools. According to Education Statistics (2016), there were 540, 290 students enrolled in National Type Chinese schools and this accounts to 20 percent of enrolment at the primary school level. National Type Chinese Schools are government-aided schools who receive partial funding in terms of per capita grant for academic and non-academic. However, these schools are not entitled for maintenance funding. Among the National Type Chinese schools, there are high performing schools or cluster schools. These schools have received extra allocation compared to other normal government-aided schools. This study was conducted to analyse whether the differences in financial allocation to schools will affect students' performance. Kenayathulla (2014) argues that sufficient financing has to be provided to ensure access to quality education regardless of ethnicity. Since the National Type Chinese schools consist of both higher performing school and lower performing school, this study also wanted to find the differences of teachers' perception in school level factors that affect students' performance in UPSR examinations.

Thus, the purpose of this research is to identify whether gaps exist in resources between higher performing schools and lower performing National Type Chinese schools. Furthermore, this research also analysed school level factors that determine students' performance in Primary School Achievement Test (in Malay commonly known as Ujian Pencapaian Sekolah Rendah) [UPSR]. Previous studies did not address school level factors in Chinese primary schools in Malaysian context. Thus, this study provides useful insight to policy makers, general public and school management on the school level resources that need to be considered in increasing students' performance, thus improving school effectiveness.

\section{THEORETICAL FOUNDATION}

The theoretical foundation for this research was based on Education Production Function. According to Hanushek (1979), education production function represents a set of education outputs which are merged with all education inputs. However, all the education inputs are applied efficiently under the assumption of the education. Education production function is a function that relates various inputs and outputs of education. The theory helps the school to increase student performance with optimal input mix. The inputs include schools, peers and families and the 


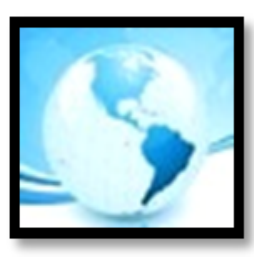

\section{MALAYSIAN ONLINE JOURNAL OF EDUCATIONAL MANAGEMENT (MOJEM)}

output of education which normally is students' achievement. The inputs of education that affect students' achievement can be obtained from time to time (Glewwe \& Lambert, 2010).

In most research work, family background of a student is characterized by the child's socio-demographic characteristics. Usually researchers use parental education, family size, income to test the socio-demographic characteristics as an input of education process. Besides, a peer input when included is particularly aggregates of student socio-demographic characteristics. There are three types of school factors: school organization, teacher background and district/community factors. Firstly, the school organization refers to the facilities in school, class sizes, administrative expenditures and so forth. However, the teacher background refers to the education level of the teacher, teacher experience, race of teacher and so forth. The average expenditure levels are an example for district/community factors as input of education process (Hanushek, 2007, 2010).

The first important category that affects education outcomes is school inputs. School inputs are normally measured by class size, funding levels, teachers' experience, or teachers' education. Besides that, school inputs are also measured by the availability of resources such as textbooks and computers. The second one is family effect or other non-school inputs. These inputs become important after the Coleman Report (1966). The report has indicated that those education outcomes are mostly determined by the students' family background compared to the school resources.

Educational outputs are commonly referred to students' performance in cognitive or non-cognitive achievement or quality of the school. As a norm, the output of education is measured by standardized student achievement test scores. Some evidences of the studies show that the researchers measured the output with student attitudes, student attendance rates and college continuation or dropout rates. Figure 1 below presents the conceptual framework of the research:

\section{Inputs}

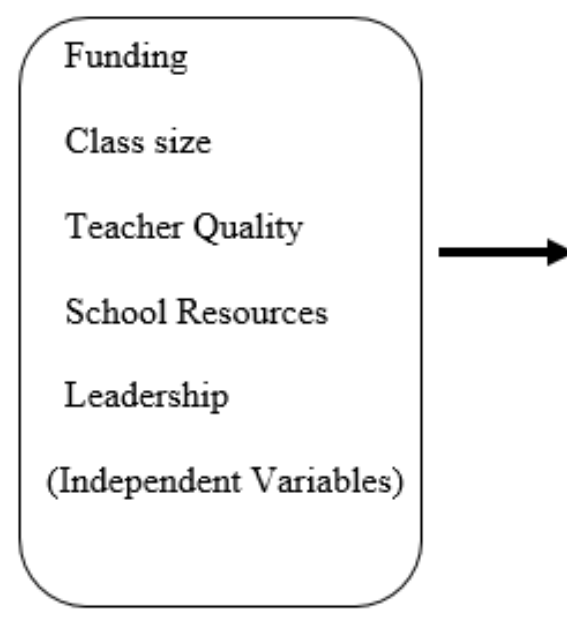

Process

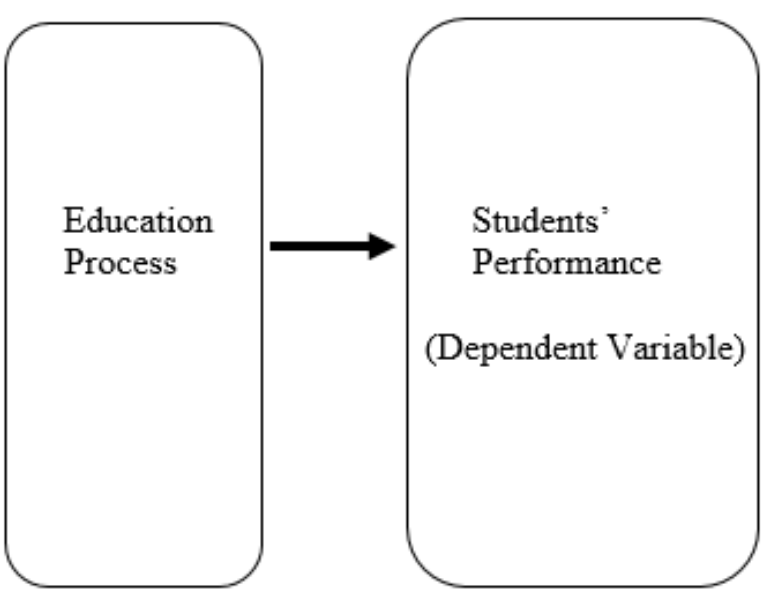

Figure 1. Conceptual Framework of Research (Modified from A context-input-process- outcome framework for school effectiveness, in Levacic \& Vignoles, 2002, p. 317).

Figure 1 shows the school level factors that are used by schools in improving students' performance (based on the Education Production Function). The independent variables consist of various factors that influence students' achievement such as location of school, school funding, number of teachers, class size, teacher experience, 


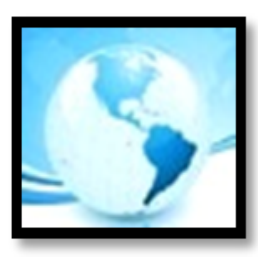

\section{MALAYSIAN ONLINE JOURNAL OF EDUCATIONAL MANAGEMENT (MOJEM)}

instructional materials, science laboratory, teacher shortage, school leadership. In this research, the dependent variable is students' performance.

\section{LITERATURE REVIEW}

\section{Factors that Determine Students' Performance}

There are various school level and family level factors that determine students' performance. However, in this article, the focus will be on school level factors that determine students' performance.

\section{School Infrastructure}

Instructional materials such as textbook, instructional place such as classroom, computers, library materials, cooling or lighting systems, science laboratory equipment and material. Numerous studies showed that school infrastructure determines students' academic achievement. Lack of school resources such as libraries, computers, and textbooks will affect students in learning and directly influence student test result (New York Comprehensive Center, 2011; Engin-Demir, 2009).

Many researches showed that schools have libraries to support students in learning. They were particularly built to help students advance in the technological and literacy areas. Besides, students may need its support in getting information and accessing resources or equipment. The libraries support was successful as shown when the New York Comprehensive Center (2011) in a study demonstrated that school libraries had positive impact on the implementation of the Regents Reform Agenda in New York. The study generally concluded that school libraries had positive influence on students' achievement. Therefore, school libraries are important in promoting student achievement and in closing the achievement gaps among students.

Learning tools and computers are school level variables that affect students' performance. These two school level variables were significant in affecting students' performance. The shortage of learning tools and computers caused students cannot perform well in their study (Lounkaew, 2013).

\section{Teachers Quality}

Teacher quality refers to teachers' experience, teachers' degrees, teachers' certification, teachers' own test score or teachers' ability. Several researches examined the impact of teacher characteristics on teacher effectiveness and overall it showed a positive effect. Furthermore, numerous researches tested teacher quality and student achievement. From several findings, teacher quality was shown to have effect on student performance (Buddin \& Zamarro, 2009).

Blazar (2015) conducted an effective teaching on measuring students' performance and found that inquiryoriented instruction had influence on student performance. Students could gain more knowledge through this type of instruction, then raising their test scores in mathematics test. However, the result also revealed that classroom climate or classroom management did not influence students' mathematics achievement. The researcher noticed that his finding varies with other research findings which showed classroom climate influence the student achievement actually. He also claimed that classroom emotional support was not related to the students' performance. 


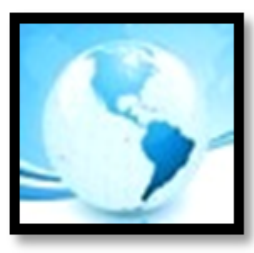

MALAYSIAN ONLINE JOURNAL OF

EDUCATIONAL MANAGEMENT

(MOJEM)

\section{Teacher Training}

Teacher training helps to improve teacher instructional practices. The implementation of training for teachers in school is expected produce more professional teachers who are able to teach with high national standard. Teachers who really want to learn or volunteer to attend training courses would earn more theoretical knowledge. Then, the teachers with their own understanding, practical skills, competencies and commitment are able to enhance students learning and produce high academic achievement students. Many studies tested the effect of teacher training on student performance. However, there were mixed results on the matter. Some evidence indicated that teacher training positively contributed to students' achievement meanwhile teacher training was insignificant to students' achievement (Fuje \& Tandon, 2016; Krishna, 2014; Naoreen, Aslam, Arshad, \& Nausheen, 2011).

Krishna (2014) examined the factors that determine educational quality in student mathematics performance. The result showed a positive significant correlation between teacher training and students' performance. Meanwhile Ping (2008) contended that teachers who had attended training under the World Bank projects had more impact on student school adaptability. Naoreen et al. (2011) identified the impact of teacher training on students' achievement in Mathematics subject. They found that neither male nor female trained teachers contribute to students' performance.

Fuje and Tandon (2016) conducted research in identifying the impact of in-service teacher training and books on students' performance. They found that students who had received books in class showed impact on increasing students' performance. In-service teacher training also had weak influence on students' performance. However, they claimed that the extra teacher training for school teachers did not affect students' performance. Extra teacher training alone did not result in improvement in students' total test score. Findings indicated that when the teacher training and books were provided together for students, then only it could increase students' test score and then improve students' performance.

Harris and Sass (2011) found that formal training for teachers in school did not increase students' performance. Their finding also showed that students' performance was not influenced by in-service professional development. Otherwise, in-service professional development of teachers only shows a little effect on students' performance. The evidence indicated that formal pre-service or in-service training for teachers shows ineffectiveness in school. The reason might be because teacher productivity was too focused on specific curriculum. Aside from that, the effort on formal training for teachers was too standardized on specific curriculum. The education programs in teacher training might focus on different skills rather than the ones to generate students' performance.

\section{Class Size}

Class size means the total amount of students in a classroom when a teacher instructs. There is a difference of best class size among countries. In the Student-teacher Achievement Ratio (STAR) project, a class which has thirteen to seventeen students is considered smaller class size. However, the regular class size has twenty-two to twenty-five students (Jackson \& Page, 2013; Koc \& Celik, 2015). Based on the STAR project which assigned teachers and students in different size classes, numerous studies have found that students in small class could increase their achievement (Paola, Ponzo, \& Scoppa, 2013). But according to the Achievement Guarantee in Education (SAGE) project, it mentioned that a small class size has fifteen students or less in a classroom. Meanwhile, according to the California Class Size Reduction Program (CSRP), small class size means fewer than twenty students in a class (Malik Amer Atta, Asif Jamil, Muhammad Ayaz, Tahir Shah, \& Muhammad Anwar Shah, 2011).

Krishna (2014) found that student-teachers ratio had negative relationship with student academic performance. This means that children in smaller class outperform children in large class. Schools with a large class size and lack of instructional materials would affect students' learning performance. Students in large class size have less 


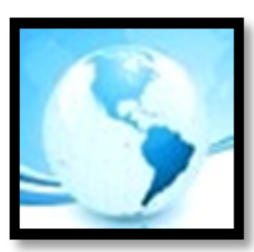

\section{MALAYSIAN ONLINE JOURNAL OF EDUCATIONAL MANAGEMENT (MOJEM)}

interaction time between them and the teacher due to the teacher being unable to focus on the individual needs of each student. In addition to that, due to the large class size, teachers faced problems in carrying out activities for students. They also have to deal with a noisier and more disruptive class environment due to the large class size.

Galton and Pell (2012) conducted a research on class size (longitudinal effects) reductions on attainment of students. They found that students in normal size class (with an average 38 students) had different attainment with students in a class with fewer than 25 pupils on a specialty test. The result showed that the effect of class sizes was in order but the small gain disappeared when students reverted back to a normal class from a small class. Researchers explained that the effects of class size were the largest for students in the smallest classes. However, these effects fade out when the students returned back to the normal size class. According to Bosworth (2014), students who struggled in their studies achieved more benefit in a small class. He found that class size only showed small effect on students' average achievement and students' achievement gaps.

\section{Factors That Determine Students' Performance in Malaysia}

In Malaysia, numerous researches were conducted to identify the factors that determine students' achievement. Most studies tested on gender, socioeconomic status, students' attitude, teachers' shortage in order to determine students' performance. Polius (2009) in his research found that students from rural area schools in Tenom, Sabah had low achievement in their academics. He identified the factors that affect students' achievement were students' attitude, parents' attitude, parents' socioeconomic status, school facilities, and shortage of teachers. Lack of school facilities in schools also had a direct effect on the students' academic achievement. In his research, the findings showed that teacher shortage, especially in critical subjects such as English, Science and Mathematics was one of the factors that influence the performance of students. This factor affected the students' academic outcome and it showed through their low achievement.

Md Yunusa, Wan Osmana and Mohd Ishaka (2011) examined whether teacher-student relationship affect students' motivation and academic achievement. From the finding, they noticed that positive relationship among teachers and students was important for students in learning English in classroom. Therefore, teacher-student relationship was able to increase students' motivation level in learning.

Low and Ishak (2012) had tested the effect of gender on students' academic achievement. They found that only family's socioeconomic and academic self-concept affected the academic performance of male and female students. They indicated that academic self-concept was important to provide confidence for students in their learning process.

Othman and Muijs (2013) conducted a test on educational quality in urban and rural primary schools in Malaysia. They tested the educational quality with 4 factors: educational resources, school leadership, school climate and involvement of parent in schools. Generally, the finding showed that educational quality among these two areas had no differences. The findings indicated that primary school regardless urban or rural schools revealed no gap among the 4 factors that tested in the study. This means that there was no significant relationship between school locations with educational quality. Teachers were mentioned alongside educational resources, school leadership, school climate and involvement of parent in schools as factors that may influence the school quality. Meanwhile, the main factors in teachers' perception was teaching and learning method alongside teachers' workload. 


\section{METHODOLOGY}

\section{Research Design}

According to Creswell (2014), quantitative research design is useful in collecting numerical data and statistical analysis for a study. In this research, the descriptive data for school and teachers are reporting by school background information, teachers' characteristic and students' academic performance of the students in school. Chua (2013) noted that descriptive statistics is an important way to organize and summarize the numerical data which are collected from questionnaire. Thus, descriptive statistics is used in this research. Figure 1 showed the research design used for this research.

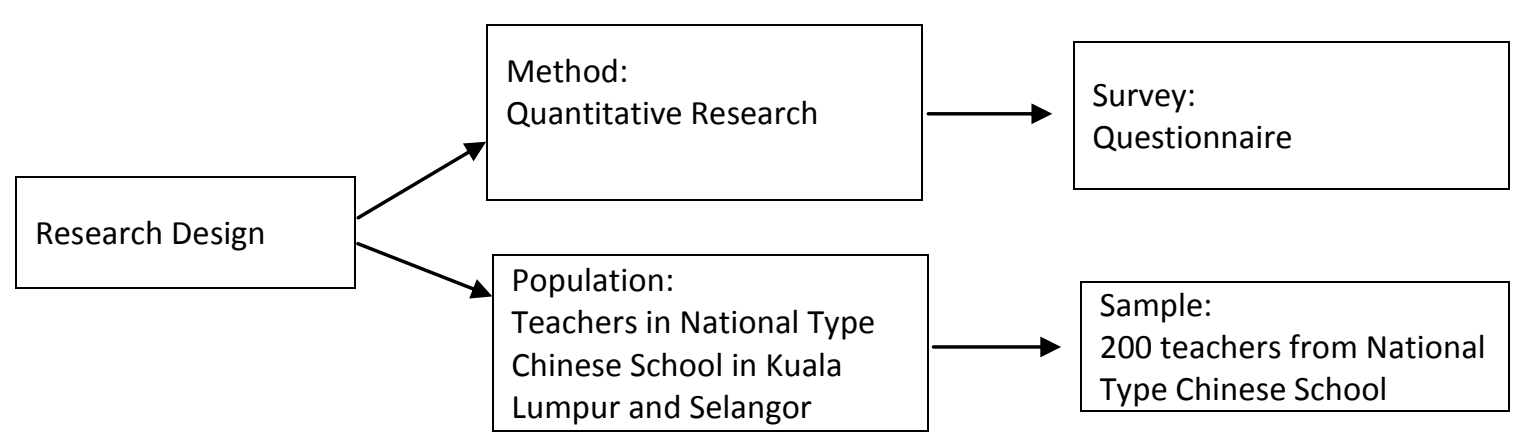

Figure 2. Research Design of Research

\section{Population and Sampling}

This research was conducted in Kuala Lumpur and Selangor (refer to Table 1), which has a high number of Chinese primary schools in Malaysia. The questionnaire was distributed to 10 schools in Kuala Lumpur and 10 schools in Selangor.

Table 1

National Type Chinese Schools selected for research

\begin{tabular}{lccc}
\hline & $\begin{array}{c}\text { Normal and Lower } \\
\text { Performing Schools }\end{array}$ & Cluster Schools & High Performing Schools \\
\hline Kuala Lumpur & 7 & 2 & 1 \\
Selangor & 7 & 2 & 1 \\
\hline
\end{tabular}

\section{Instrumentation}

A questionnaire was used to gather information in this study. The questionnaire consisted of three sections which are classified as Section A (School Background Information), Section B (Academic Performance of the School), and Section C (Factors that determine students' performance). The questionnaires were developed based on literature and validated by two experts in the field.

The information to be gathered from Section A consisted of two parts. The first part was mainly focusing on the schools' background information which included location, area of location, type of school, average of school ranking, number of teachers, number of graduate teachers, years of experience, students' enrolment, and socioeconomic status of students' parents, average number of students in each class, school category and funds 


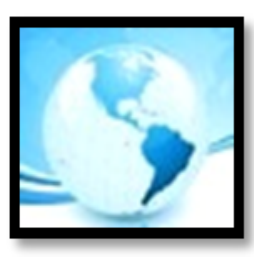

\section{MALAYSIAN ONLINE JOURNAL OF EDUCATIONAL MANAGEMENT (MOJEM)}

allocated by the government per year. The second part was teachers' background information. This part included teachers' gender, age, race, teaching experiences and academic status. Respondents need to choose the appropriate information.

Section B sought information about the academic performance of the school. This part needs to indicate the achievement of UPSR candidates in year 2014. Respondents need to fill in the UPSR School Average Grade and passing rate. Besides that, they need to also fill in the number of students who scored 7As, 6As, 5As, 4As, 3As as well as number of students who pass all subjects.

Furthermore, Section C continues with factors that determined students' performance. Respondents need to tick the appropriate answers based on their opinions. The answers in Section $C$ utilize the four-point Likert scale: strongly disagree, disagree, agree, and strongly agree. The Likert scale consists of a set of statements. The statements are judged with the rating scale (Newby, 2010). It is important to collect the response of respondents from different schools using the four units long rating scale. In this research, all the factors that determine students' achievement are rated by the four-point Likert scale. According to Asún, Rdz-Navarro and Alvarado (2016), the four-point Likert scale can be interesting when the social desirability is considered to have an effect on any construct intended to be measured and subjects are heterogeneous in their abilities to do discrimination among categories. There are 12 parts in section C (school facility, library, technology, instructional materials, science laboratory, teachers' attitude, teachers' attitude, teacher training, and teachers' ability, shortage of teachers, peers coaching, professional learning community, and leadership in schools). For each part, there are 8 items.

\section{Data Collection Procedure}

This study was designed to identify the school level factors that determine students' performance in UPSR examinations, which is the national examination taken by all students after six years of primary education. The study was conducted in Chinese primary schools in Kuala Lumpur and Selangor. Before conducting the research in schools, the researcher had applied for letter of approval and received permission from the Educational Planning and Research Division (EPRD) of Malaysia's Ministry of Education. Upon receiving the approval letter from EPRD, the researcher sent the approval letter to the Selangor State Education Department and Kuala Lumpur State Education Department to inform them of the purpose of doing the research in the selected schools.

After receiving the approval letter from the two states of education department, a pilot test for the research was conducted in two schools in Kuala Lumpur to examine the reliability and validity of the questionnaire. The questionnaires were distributed to teachers in these two schools and were collected back after three days.

\section{Data Analysis Process}

This research's focus was to identify the school level factors that determined Chinese primary school students' performance in UPSR examination. After collecting the data through questionnaire, the next important procedure is data analysis process. This part is important in order to analyse the research questions in this research. Statistical Package for the Social Science (SPSS) version 22 is used for analysing the data of this research. There are three research questions in this research. The following table shows the research questions and the test used.

T-tests were used to analyse the differences between higher performing and lower performing Chinese Primary school teachers' perception on the availability of school' resources. In addition to that, in order to identify the school level factors that determine students' performance in UPSR examination, multiple regression analysis tests were also used. 


\section{Reliability of Questionnaire}

A pilot test is important for a research in order to check the reliability of items in questionnaire. Reliability identifies the correlation between scores for each item or total scores for all items in questionnaire. The acceptable range for Cronbach's alpha reliability is from .65 to .95 alpha values (Chua, 2013).

Table 2

Reliability statistics of pilot test

\begin{tabular}{llll}
\hline Part & Aspect & Number of Items & Cronbach Alpha \\
\hline Part 1 & School Facility & 8 & 0.702 \\
Part 2 & School Library & 8 & 0.779 \\
Part 3 & School Technology & 8 & 0.850 \\
Part 4 & Instructional Materials & 8 & 0.705 \\
Part 5 & Science Laboratory & 8 & 0.891 \\
Part 6 & Teachers' Attitude & 8 & 0.753 \\
Part 7 & Teacher Training & 8 & 0.818 \\
Part 8 & Teachers' Ability & 8 & 0.826 \\
Part 9 & Shortage of Teachers & 8 & 0.701 \\
Part 10 & Peer Coaching & 8 & 0.863 \\
Part 11 & Professional Learning Community & 8 & 0.954 \\
Part 12 & Leadership in School & 8 & 0.903 \\
\hline
\end{tabular}

Table 2 showed the reliability of items in 12 parts and all items in the questionnaire. Data showed the Cronbach Alpha of each part to be: 0.702 (Part 1), 0.779 (Part 2), 0.850 (Part 3), 0.705 (Part 4), 0.891 (Part 5), 0.753 (Part 6), 0.818 (Part 7), 0.826 (Part 8), 0.701 (Part 9), 0.863 (Part 10), 0.954 (Part 11), 0.903 (Part 12). The questionnaire was proven to be reliable because all the reliability obtained more than 0.7 .

\section{FINDINGS}

The section below shows the demographic information of the participants that were involved in this research.

\section{Demographic Information of the Participants}

\section{Gender}

Table 3 showed that 84.5 percent of the respondents were female teachers while 15.5 percent of the respondents were male teachers. 


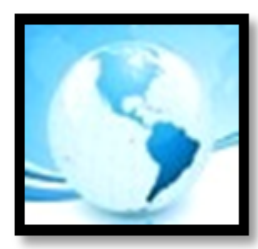

Table 3

Teachers'gender

\begin{tabular}{lcc}
\hline & Frequency & Percent \\
\hline Male & 31 & 15.5 \\
Female & 169 & 84.5 \\
Total & 200 & 100.0 \\
\hline
\end{tabular}

Age

Table 4 showed that majority of the respondents were between 30-39 years old (46\%) followed by those aged between 40-50 years old (20 percent). About 17.5 percent of the respondents were between 25-29 years old. Only 8.5 percent of the respondents were below 24 years old while 8 percent were above 50 years old.

Table 4

Teachers'age

\begin{tabular}{lcc}
\hline & Frequency & Percent \\
\hline Below 24 years old & 17 & 8.5 \\
$25-29$ years old & 35 & 17.5 \\
$30-39$ years old & 92 & 46.0 \\
$40-50$ years old & 40 & 20.0 \\
Above 50 years old & 16 & 8.0 \\
Total & 200 & 100.0 \\
\hline
\end{tabular}

\section{Academic Status}

Table 5 showed that majority of the teachers are degree holders (72 percent). Meanwhile, 21 percent of the teachers were diploma holders. About 3.5 percent of the teachers have master degree and 3.5 percent teachers have other qualifications.

Table 5

Teachers' academic status

\begin{tabular}{lcc}
\hline & Frequency & Percent \\
\hline Diploma & 42 & 21.0 \\
Degree & 144 & 72.0 \\
Master & 7 & 3.5 \\
Others & 7 & 3.5 \\
Total & 200 & 100.0 \\
\hline
\end{tabular}

\section{Average of School Ranking (BAND)}

Band for a school is based on the composite score of UPSR examination Grade Point Average (GPS) and school performance rating score is by the Malaysian Ministry of Education. Normally, there are 6 bands in primary school. Band 1 is the best band and followed by another band in orderly. Table 6 showed that most of the respondents (42.5 percent) were teaching in Band 1 schools, 36 percent of the respondents in Band 2 schools and 11.5 percent of the respondents in Band 3 schools. Only 20 respondents were teaching in Band 4 schools. 


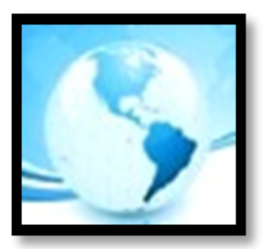

Table 6

Average of school ranking (Band)

\begin{tabular}{lcc}
\hline & Frequency & Percent \\
\hline Band 1 & 85 & 42.5 \\
Band 2 & 72 & 36.0 \\
Band 3 & 23 & 11.5 \\
Band 4 & 20 & 10.0 \\
Total & 200 & 100.0 \\
\hline
\end{tabular}

\section{School Level Resources between Higher and Lower Performing Schools}

Independent Samples T- Test was conducted to compare between higher performing and lower performing Chinese Primary school teachers' perception on the availability of school resources. The number of teachers in higher performing schools that were involved in this study was 105, while the sample of teachers from lower performing schools was 95 .

Table 7

Summary of independent-samples t test for both group on school facility

\begin{tabular}{|c|c|c|c|c|c|c|c|c|c|c|}
\hline \multirow[t]{2}{*}{ School Facility } & \multirow[t]{2}{*}{ Group of schools } & \multirow[t]{2}{*}{ Mean } & \multirow[t]{2}{*}{$S D$} & \multirow[t]{2}{*}{$T$} & \multirow[t]{2}{*}{$d f$} & \multirow[t]{2}{*}{$P$} & \multicolumn{2}{|l|}{$\begin{array}{l}95 \% \mathrm{Cl} \text { of the } \\
\text { Difference }\end{array}$} & \multicolumn{2}{|c|}{$\begin{array}{l}\text { Levene's Test } \\
\text { for Equality of } \\
\text { Variances }\end{array}$} \\
\hline & & & & & & & Lower & Upper & $\mathrm{F}$ & Sig. \\
\hline \multirow{2}{*}{$\begin{array}{l}\text { Safe classrooms are available in } \\
\text { school }\end{array}$} & Higher performing & 3.23 & .505 & -2.09 & 196 & .038 & -.292 & -.009 & 4.756 & .030 \\
\hline & Lower performing & 3.38 & .509 & & & & & & & \\
\hline \multirow{2}{*}{$\begin{array}{l}\text { Air-conditioning is available in all } \\
\text { classrooms }\end{array}$} & Higher performing & 2.59 & 1.09 & -1.74 & 198 & .083 & -.559 & .034 & 1.925 & .167 \\
\hline & Lower performing & 2.85 & 1.03 & & & & & & & \\
\hline \multirow[t]{2}{*}{ School buildings are in order } & Higher performing & 3.21 & .583 & 1.17 & 198 & .243 & -.071 & .280 & .000 & .995 \\
\hline & Lower performing & 3.11 & .676 & & & & & & & \\
\hline \multirow{2}{*}{$\begin{array}{l}\text { Places for students to conduct } \\
\text { discussions are provided }\end{array}$} & Higher performing & 2.88 & .532 & -2.01 & 198 & .046 & -.329 & -.003 & 1.044 & .308 \\
\hline & Lower performing & 3.04 & .634 & & & & & & & \\
\hline \multirow{2}{*}{$\begin{array}{l}\text { Damaged facilities are replaced by } \\
\text { school }\end{array}$} & Higher performing & 3.13 & .440 & -.38 & 198 & .703 & -.151 & .102 & .751 & .387 \\
\hline & Lower performing & 3.16 & .468 & & & & & & & \\
\hline \multirow{2}{*}{$\begin{array}{l}\text { Students are given chance to use all } \\
\text { the school facilities }\end{array}$} & Higher performing & 3.16 & .483 & 1.06 & 198 & .293 & -.068 & .223 & .329 & .567 \\
\hline & Lower performing & 3.08 & .559 & & & & & & & \\
\hline \multirow{2}{*}{$\begin{array}{l}\text { School provides water machine to } \\
\text { students }\end{array}$} & Higher performing & 3.33 & .599 & -.307 & 198 & .759 & -.182 & .133 & .330 & .567 \\
\hline & Lower performing & 3.36 & .524 & & & & & & & \\
\hline School supplies comfortable & Higher performing & 2.70 & .619 & -.005 & 184 & .996 & -.192 & .191 & 3.967 & .048 \\
\hline playground to students & Lower performing & 2.71 & .742 & & & & & & & \\
\hline
\end{tabular}

Higher performing school, $\mathrm{N}=105$; Lower performing school, $\mathrm{N}=95$

$* p<.05$ 


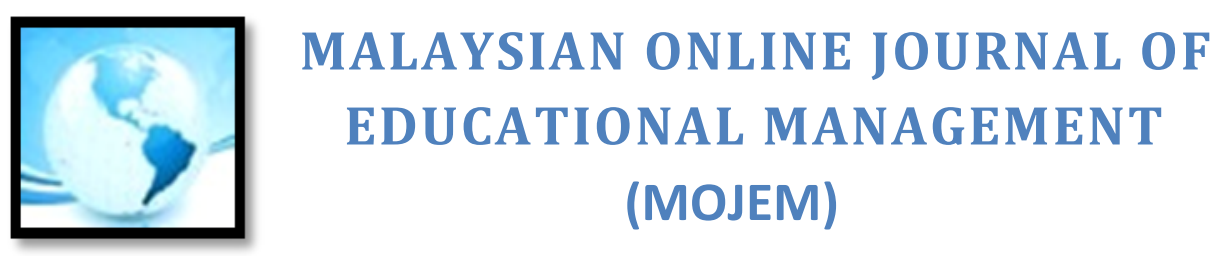

Based on Table 7, the result indicated that there are significant differences between higher performing ( $\mathrm{M}=3.23$, $\mathrm{SD}=.51)$ and lower performing $(\mathrm{M}=3.38, \mathrm{SD}=.51)$ school teachers' perception on the availability of safe classrooms, $t(196)=-2.09, p=.038$. The mean for teachers from higher performing schools is less than the mean for teachers from lower performing schools in their perceptions on the availability of safe classrooms.

The result also showed that there are significant differences between higher performing $(M=2.88, S D=.53)$ and lower performing $(M=3.04, S D=.63)$ school teachers' perception on the availability of places for students' discussion, $t(198)=-2.01, p=.046$. Thus, the findings indicate that the mean for teachers from higher performing schools is less than lower performing schools in terms of place for discussions. These findings indicate that teachers in lower performing schools highly perceive in terms of availability of safe classrooms and place for discussion.

Table 8

Summary of independent-samples t test for both group on school library

\begin{tabular}{|c|c|c|c|c|c|c|c|c|c|c|}
\hline \multirow[t]{2}{*}{ School Library } & \multirow[t]{2}{*}{ Group of school } & \multirow[t]{2}{*}{ Mean } & \multirow[t]{2}{*}{$S D$} & \multirow[t]{2}{*}{$T$} & \multirow[t]{2}{*}{$d f$} & \multirow[t]{2}{*}{$P$} & \multicolumn{2}{|c|}{$\begin{array}{l}95 \% \mathrm{Cl} \text { of the } \\
\text { Difference }\end{array}$} & \multicolumn{2}{|c|}{$\begin{array}{l}\text { Levene's Test } \\
\text { for Equality of } \\
\text { Variances }\end{array}$} \\
\hline & & & & & & & Lower & Upper & $\mathrm{F}$ & Sig. \\
\hline \multirow[t]{2}{*}{ School library has the latest books } & Higher performing & 3.18 & .533 & 2.252 & 198 & .025 & .021 & .320 & 2.941 & .088 \\
\hline & Lower performing & 3.01 & .536 & & & & & & & \\
\hline There are more than 2000 books in & Higher performing & 3.39 & .509 & 3.582 & 194 & .000 & .119 & .410 & 9.047 & .003 \\
\hline library & Lower performing & 3.13 & .531 & & & & & & & \\
\hline \multirow[t]{2}{*}{ Different types of books are available } & Higher performing & 3.40 & .492 & 2.896 & 192 & .004 & .067 & .354 & 5.836 & .017 \\
\hline & Lower performing & 3.19 & .532 & & & & & & & \\
\hline \multirow[t]{2}{*}{ Books for enrichment are available } & Higher performing & 3.25 & .515 & 2.116 & 198 & .036 & .011 & .316 & 1.584 & .210 \\
\hline & Lower performing & 3.08 & .577 & & & & & & & \\
\hline \multirow[t]{2}{*}{ Students borrow more than 2 books } & Higher performing & 2.79 & .716 & -.513 & 198 & .609 & -.250 & .147 & .070 & .791 \\
\hline & Lower performing & 2.84 & .704 & & & & & & & \\
\hline \multirow[t]{2}{*}{ Provides online reading for students } & Higher performing & 2.44 & .733 & 1.270 & 198 & .206 & -.073 & .339 & .010 & .922 \\
\hline & Lower performing & 2.31 & .745 & & & & & & & \\
\hline \multirow[t]{2}{*}{ Always increases reading materials } & Higher performing & 3.03 & .489 & -.765 & 198 & .445 & -.199 & .088 & 3.225 & .074 \\
\hline & Lower performing & 3.08 & .539 & & & & & & & \\
\hline \multirow{2}{*}{$\begin{array}{l}\text { Provides reading programmes for } \\
\text { students }\end{array}$} & Higher performing & 3.04 & .458 & -1.531 & 198 & .127 & -.226 & .028 & 1.897 & .170 \\
\hline & Lower performing & 3.14 & .452 & & & & & & & \\
\hline
\end{tabular}

Higher performing school, $\mathrm{N}=105$; Lower performing school, $\mathrm{N}=95$

$* p<.05$

Table 8 showed the differences in the perceptions of high performing school teachers and lower performing school teachers in terms of school library. From the analysis in Table 8, the result showed that there is significant difference between higher performing $(M=3.18, S D=.53)$ and lower performing $(M=3.01, S D=.54)$ school teachers' perception on the availability of latest books in library, $t(198)=2.252, p=.025$. Higher performing school teachers' perception had higher mean than lower performing school teachers. Thus, the findings indicate that teachers in higher performing schools perceive that their schools have the latest books.

Result also showed that there is significant difference between higher performing $(M=3.39, S D=.51)$ and lower performing $(M=3.13, S D=.53)$ school teachers' perception on the availability of more than 2000 books in school library, $t(194)=3.582, p=.000$. The mean score of higher performing school teachers' perception is higher than the lower performing school teachers' perception. Based on the mean score, this indicates that the higher performing teachers perceive that their school library has more than 2000 books.

Based on the result, the higher performing school teachers' perception on the availability of different types of books in school library $(M=3.40, S D=.49)$ and lower performing school $(M=3.19, S D=.53)$, was statistically 


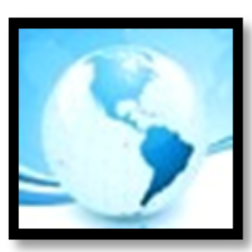

significant, $t(192)=2.896, p=.004$. The mean score of the higher performing school teachers' perception is higher than the lower performing school teachers' perception. Thus, the data provide sufficient evidence to conclude that teachers in higher performing schools perceive that their school library had provided different types of books for students.

The result indicated that there is significant difference between higher performing $(M=3.25, S D=.52)$ and lower performing $(M=3.08, S D=.58)$ school teachers' perception on the availability of books for enrichment in school library, $t(198)=2.116, p=.036$. Based on the result, the higher performing school teachers' perception has higher mean than the lower performing school teachers' perception. This reveals that the teachers in higher performing schools perceive that their schools have more books for enrichment in school library.

Table 9

Summary of independent-samples $t$ test for both group on school technology

\begin{tabular}{|c|c|c|c|c|c|c|c|c|c|c|}
\hline \multirow[t]{2}{*}{ School Technology } & \multirow[t]{2}{*}{ Group of schools } & \multirow[t]{2}{*}{ Mean } & \multirow[t]{2}{*}{$S D$} & \multirow[t]{2}{*}{$t$} & \multirow[t]{2}{*}{$d f$} & \multirow[t]{2}{*}{$p$} & \multicolumn{2}{|c|}{$\begin{array}{l}95 \% \mathrm{Cl} \text { of the } \\
\text { Difference }\end{array}$} & \multicolumn{2}{|c|}{$\begin{array}{l}\text { Levene's Test for } \\
\text { Equality of } \\
\text { Variances }\end{array}$} \\
\hline & & & & & & & Lower & Upper & $F$ & Sig. \\
\hline \multirow{2}{*}{$\begin{array}{l}\text { Computer laboratories are sufficient } \\
\text { in school }\end{array}$} & Higher performing & 2.96 & .587 & .805 & 198 & .422 & -.097 & .232 & .244 & .622 \\
\hline & Lower performing & 2.89 & .592 & & & & & & & \\
\hline \multirow{2}{*}{$\begin{array}{l}\text { Each student can use computer } \\
\text { individually for learning }\end{array}$} & Higher performing & 2.79 & .675 & 1.114 & 198 & .267 & -.082 & .294 & 2.157 & .143 \\
\hline & Lower performing & 2.68 & .673 & & & & & & & \\
\hline \multirow{2}{*}{$\begin{array}{l}\text { High speed internet service is } \\
\text { provided in computer labs }\end{array}$} & Higher performing & 2.79 & .631 & 3.271 & 173 & .001 & .138 & .559 & 16.69 & .000 \\
\hline & Lower performing & 2.44 & .847 & & & & & & & \\
\hline \multirow{2}{*}{$\begin{array}{l}\text { Computer labs are well-equipped with } \\
\text { latest software }\end{array}$} & Higher performing & 2.94 & .477 & 3.333 & 173 & .001 & .110 & .429 & 26.284 & .000 \\
\hline & Lower performing & 2.67 & .643 & & & & & & & \\
\hline \multirow{2}{*}{$\begin{array}{l}\text { Educational media/instructional } \\
\text { television are provided }\end{array}$} & Higher performing & 2.87 & .573 & -.749 & 198 & .455 & -.217 & .097 & 1.892 & .171 \\
\hline & Lower performing & 2.93 & .550 & & & & & & & \\
\hline \multirow{2}{*}{$\begin{array}{l}\text { Teachers use VLE-Frog to teach in } \\
\text { classroom }\end{array}$} & Higher performing & 2.89 & .445 & 3.306 & 163 & .001 & .107 & .423 & 33.828 & .000 \\
\hline & Lower performing & 2.62 & .655 & & & & & & & \\
\hline \multirow{2}{*}{$\begin{array}{l}\text { Teaching aids such as scanner, } \\
\text { projector are used in classroom }\end{array}$} & Higher performing & 3.15 & .690 & -.060 & 198 & .952 & -.185 & .174 & 3.231 & .074 \\
\hline & Lower performing & 3.16 & .589 & & & & & & & \\
\hline \multirow{2}{*}{$\begin{array}{l}\text { Latest model of computers are being } \\
\text { used in the classroom }\end{array}$} & Higher performing & 2.84 & .761 & 2.431 & 198 & .016 & .051 & .488 & 3.126 & .079 \\
\hline & Lower performing & 2.57 & .808 & & & & & & & \\
\hline
\end{tabular}

Higher performing school, $\mathrm{N}=105$; Lower performing school, $\mathrm{N}=95$

$* p<.05$

Table 9 is on teachers' perception on the availability of school technology. The results showed that there is significant difference in the perceptions of higher performing school teachers $(M=2.79, S D=.63)$ and lower performing school teachers $(M=2.44, S D=.85)$ on the availability of high speed internet service in computer labs, $t(173)=3.271, p=.001$. Thus, the data provide sufficient evidence that the teachers' in higher performing schools perceive that their schools have provided high speed internet service in school.

From the analysis, it shows that there is significant difference in the perceptions of higher performing school teachers $(M=2.94, S D=.48)$ and lower performing school teachers $(M=2.67, S D=.64)$ in the availability of computer labs with the latest software/program, $\mathrm{t}(173)=3.333, \mathrm{p}=.001$. Based on the result, teachers in higher performing schools highly perceive that their schools have computer labs with the latest technology.

The result shows that there is significant difference between higher performing $(M=2.89, S D=.45)$ and lower performing $(M=2.62, S D=.66)$ school teachers' perception on teaching using VLE-Frog in classroom, $t(163)=3.306$, $\mathrm{p}=.001$. This indicates that teachers in higher performing school highly perceive that the teachers teach using VLEFrog. 
Based on Table 9, the result indicates a significant difference between higher performing $(M=2.84, S D=.76)$ and lower performing $(\mathrm{M}=2.57, \mathrm{SD}=.81)$ school teachers' perception on the availability of the latest model of computers in the classroom, $\mathrm{t}(198)=2.431, \mathrm{p}=.016$. The mean is higher for perceptions of higher performing school teachers compared to lower performing school teachers. This indicates that teachers in higher performing schools are given chances to use the latest models of computer in their teaching sessions.

Table 10

Summary of independent-samples t test for both group on teachers' ability

\begin{tabular}{|c|c|c|c|c|c|c|c|c|c|c|}
\hline \multirow[t]{2}{*}{ Teachers' Ability } & \multirow[t]{2}{*}{ Group of schools } & \multirow[t]{2}{*}{ Mean } & \multirow[t]{2}{*}{$S D$} & \multirow[t]{2}{*}{$t$} & \multirow[t]{2}{*}{$d f$} & \multirow[t]{2}{*}{$p$} & \multicolumn{2}{|c|}{$\begin{array}{l}95 \% \mathrm{Cl} \text { of the } \\
\text { Difference }\end{array}$} & \multicolumn{2}{|c|}{$\begin{array}{l}\text { Levene's Test for } \\
\text { Equality of } \\
\text { Variances }\end{array}$} \\
\hline & & & & & & & Lower & Upper & $F$ & Sig. \\
\hline $\begin{array}{l}\text { I am able to manage students' discipline } \\
\text { problems }\end{array}$ & $\begin{array}{l}\text { Higher performing } \\
\text { Lower performing }\end{array}$ & $\begin{array}{l}3.19 \\
3.19\end{array}$ & $\begin{array}{l}.482 \\
.468\end{array}$ & .015 & 198 & .988 & -.132 & .134 & .075 & .785 \\
\hline $\begin{array}{l}\text { I am able to impart extra knowledge } \\
\text { effectively to students }\end{array}$ & $\begin{array}{l}\text { Higher performing } \\
\text { Lower performing }\end{array}$ & $\begin{array}{l}3.15 \\
3.15\end{array}$ & $\begin{array}{l}.387 \\
.385\end{array}$ & .092 & 198 & .927 & -.103 & .113 & .018 & .893 \\
\hline $\begin{array}{l}\text { I always negotiate with students so that } \\
\text { they learn well }\end{array}$ & $\begin{array}{l}\text { Higher performing } \\
\text { Lower performing }\end{array}$ & $\begin{array}{l}3.15 \\
3.05\end{array}$ & $\begin{array}{l}.361 \\
.470\end{array}$ & 1.693 & 198 & .092 & -.016 & .216 & .000 & .983 \\
\hline $\begin{array}{l}\text { I am able to deliver my knowledge of } \\
\text { the subject }\end{array}$ & $\begin{array}{l}\text { Higher performing } \\
\text { Lower performing }\end{array}$ & $\begin{array}{l}3.16 \\
3.21\end{array}$ & $\begin{array}{l}.395 \\
.410\end{array}$ & -.854 & 198 & .394 & -.161 & .064 & 1.558 & .213 \\
\hline $\begin{array}{l}\text { I only impart true and valid knowledge } \\
\text { or information }\end{array}$ & $\begin{array}{l}\text { Higher performing } \\
\text { Lower performing }\end{array}$ & $\begin{array}{l}3.10 \\
3.16\end{array}$ & $\begin{array}{l}.390 \\
.445\end{array}$ & -.899 & 198 & .370 & -.170 & .063 & 3.390 & .067 \\
\hline $\begin{array}{l}\text { I am using different skills to teach } \\
\text { different types of students }\end{array}$ & $\begin{array}{l}\text { Higher performing } \\
\text { Lower performing }\end{array}$ & $\begin{array}{l}3.12 \\
3.15\end{array}$ & $\begin{array}{l}.385 \\
.437\end{array}$ & -.406 & 198 & .686 & -.138 & .091 & 1.657 & .199 \\
\hline $\begin{array}{l}\text { I help my students to love and learn } \\
\text { well in the subject I teach }\end{array}$ & $\begin{array}{l}\text { Higher performing } \\
\text { Lower performing }\end{array}$ & $\begin{array}{l}3.20 \\
3.15\end{array}$ & $\begin{array}{l}.425 \\
.412\end{array}$ & .887 & 198 & .376 & -.064 & .170 & 1.509 & .221 \\
\hline $\begin{array}{l}\text { My classroom management is good } \\
\text { (students are obedient during lessons) }\end{array}$ & $\begin{array}{l}\text { Higher performing } \\
\text { Lower performing }\end{array}$ & $\begin{array}{l}3.05 \\
3.18\end{array}$ & $\begin{array}{l}.350 \\
.525\end{array}$ & -2.057 & 161 & .041 & -.257 & -.005 & 25.931 & .000 \\
\hline
\end{tabular}

Higher performing school, $\mathrm{N}=105$; Lower performing school, $\mathrm{N}=95$

$* p<.05$

Table 10 showed the perceptions of higher and lower performing school teachers on classroom management. The findings indicate that teachers in higher performing and lower performing school do not differ in terms of classroom management except for one item. The result indicates that there is significant difference between higher performing $(\mathrm{M}=3.05, \mathrm{SD}=.35)$ and lower performing $(\mathrm{M}=3.18, \mathrm{SD}=.53)$ school teachers' perception in terms of their ability to manage class effectively, $\mathrm{t}(161)=-2.057, \mathrm{p}=.041$. From this analysis, it can be concluded that teachers from lower performing schools highly perceive in terms of their ability to manage class effectively. 


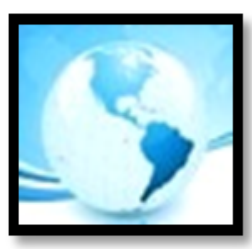

MALAYSIAN ONLINE JOURNAL OF

EDUCATIONAL MANAGEMENT

(MOJEM)

Table 11

Summary of independent-samples $t$ test for both group on shortage of teachers

\begin{tabular}{|c|c|c|c|c|c|c|c|c|c|c|}
\hline \multirow[t]{2}{*}{ Shortage of teachers } & \multirow[t]{2}{*}{ Group of schools } & \multirow[t]{2}{*}{ Mean } & \multirow[t]{2}{*}{$S D$} & \multirow[t]{2}{*}{$T$} & \multirow[t]{2}{*}{$d f$} & \multirow[t]{2}{*}{$p$} & \multicolumn{2}{|c|}{$\begin{array}{l}95 \% \mathrm{Cl} \text { of the } \\
\text { Difference }\end{array}$} & \multicolumn{2}{|c|}{$\begin{array}{c}\text { Levene's Test for } \\
\text { Equality of } \\
\text { Variances }\end{array}$} \\
\hline & & & & & & & Lower & Upper & $\mathrm{F}$ & Sig. \\
\hline \multirow[t]{2}{*}{ My school has enough of teachers } & Higher performing & 2.63 & .763 & .355 & 198 & .723 & -.178 & .256 & .164 & .686 \\
\hline & Lower performing & 2.59 & .792 & & & & & & & \\
\hline \multirow{2}{*}{$\begin{array}{l}\text { The number of subject teachers is } \\
\text { balanced and sufficient }\end{array}$} & Higher performing & 2.62 & .544 & 1.773 & 169 & .078 & -.019 & .352 & 13.749 & .000 \\
\hline & Lower performing & 2.45 & .755 & & & & & & & \\
\hline \multirow{2}{*}{$\begin{array}{l}\text { Teachers in my school teach the subject } \\
\text { they major in }\end{array}$} & Higher performing & 2.71 & .532 & .580 & 176 & .562 & -.123 & .225 & 7.046 & .009 \\
\hline & Lower performing & 2.66 & .694 & & & & & & & \\
\hline \multirow{2}{*}{$\begin{array}{l}\text { Each teacher focuses on teaching one } \\
\text { subject only }\end{array}$} & Higher performing & 2.09 & .606 & -.301 & 176 & .764 & -.227 & .167 & 4.932 & .028 \\
\hline & Lower performing & 2.12 & .784 & & & & & & & \\
\hline \multirow{2}{*}{$\begin{array}{l}\text { Teacher shortage has never happened } \\
\text { in my school }\end{array}$} & Higher performing & 2.08 & .583 & .997 & 174 & .320 & -.095 & .290 & 4.519 & .035 \\
\hline & Lower performing & 1.98 & .772 & & & & & & & \\
\hline \multirow{2}{*}{$\begin{array}{l}\text { School only faces shortage of teachers } \\
\text { in non-exam subjects }\end{array}$} & Higher performing & 2.30 & .603 & 1.906 & 198 & .058 & -.006 & .365 & .049 & .825 \\
\hline & Lower performing & 2.12 & .727 & & & & & & & \\
\hline \multirow{2}{*}{$\begin{array}{l}\text { My school has temporary teachers to } \\
\text { help in teaching }\end{array}$} & Higher performing & 2.70 & .720 & -1.404 & 198 & .162 & -.330 & .056 & 1.288 & .258 \\
\hline & Lower performing & 2.84 & .657 & & & & & & & \\
\hline \multirow{2}{*}{$\begin{array}{l}\text { Teacher shortage affects students' } \\
\text { academic performance }\end{array}$} & Higher performing & 2.88 & .840 & -2.216 & 198 & .028 & -.493 & -.029 & .051 & .822 \\
\hline & Lower performing & 3.14 & .820 & & & & & & & \\
\hline
\end{tabular}

Higher performing school, $\mathrm{N}=105$; Lower performing school, $\mathrm{N}=95$

$* p<.05$

In Table 11, result showed that there was only one item that indicates significant difference in the perceptions of higher performing school teachers $(M=2.88, S D=.84)$ and lower performing school teachers $(M=3.14, S D=.82)$, $t(198)=-2.216, p=.028$. This indicates that lower performing school teachers highly perceive that shortage of teachers in school influence students' academic performance.

Table 12

Summary of independent-samples t test for both group on leadership in school

\begin{tabular}{|c|c|c|c|c|c|c|c|c|c|c|}
\hline \multirow[t]{2}{*}{ Leadership in School } & \multirow[t]{2}{*}{ Group of schools } & \multirow[t]{2}{*}{ Mean } & \multirow[t]{2}{*}{$S D$} & \multirow[t]{2}{*}{$T$} & \multirow[t]{2}{*}{$D f$} & \multirow[t]{2}{*}{$p$} & \multicolumn{2}{|c|}{$\begin{array}{l}95 \% \mathrm{Cl} \text { of the } \\
\text { Difference }\end{array}$} & \multicolumn{2}{|c|}{$\begin{array}{c}\text { Levene's Test for } \\
\text { Equality of } \\
\text { Variances }\end{array}$} \\
\hline & & & & & & & Lower & Upper & $\mathrm{F}$ & Sig. \\
\hline $\begin{array}{l}\text { Colleagues are proud to be associated } \\
\text { with me }\end{array}$ & $\begin{array}{l}\text { Higher performing } \\
\text { Lower performing }\end{array}$ & $\begin{array}{l}2.99 \\
2.97\end{array}$ & $\begin{array}{l}.380 \\
.424\end{array}$ & .388 & 198 & .698 & -.090 & .134 & 1.941 & .165 \\
\hline $\begin{array}{l}\text { I am able to give personal attention to } \\
\text { colleagues or students }\end{array}$ & $\begin{array}{l}\text { Higher performing } \\
\text { Lower performing }\end{array}$ & $\begin{array}{l}3.00 \\
3.00\end{array}$ & $\begin{array}{l}.310 \\
.461\end{array}$ & .000 & 198 & 1.00 & -.109 & .109 & 2.007 & .158 \\
\hline $\begin{array}{l}\text { I am able to inspire my colleagues to } \\
\text { perform better }\end{array}$ & $\begin{array}{l}\text { Higher performing } \\
\text { Lower performing }\end{array}$ & $\begin{array}{l}3.00 \\
2.89\end{array}$ & $\begin{array}{l}.392 \\
.494\end{array}$ & 1.66 & 179 & .099 & -.020 & .230 & 8.137 & .005 \\
\hline $\begin{array}{l}\text { I try to make others feel good around } \\
\text { me }\end{array}$ & $\begin{array}{l}\text { Higher performing } \\
\text { Lower performing }\end{array}$ & $\begin{array}{l}3.11 \\
3.17\end{array}$ & $\begin{array}{l}.320 \\
.404\end{array}$ & -1.04 & 179 & .298 & -.156 & .048 & 6.768 & .010 \\
\hline $\begin{array}{l}\text { I give guidance or direction to my } \\
\text { colleagues }\end{array}$ & $\begin{array}{l}\text { Higher performing } \\
\text { Lower performing }\end{array}$ & $\begin{array}{l}2.95 \\
3.07\end{array}$ & $\begin{array}{l}.468 \\
.489\end{array}$ & -1.79 & 198 & .075 & -.255 & .012 & .484 & .488 \\
\hline $\begin{array}{l}\text { Colleagues listen to my ideas because of } \\
\text { my knowledge and skills }\end{array}$ & $\begin{array}{l}\text { Higher performing } \\
\text { Lower performing }\end{array}$ & $\begin{array}{l}2.84 \\
3.03\end{array}$ & $\begin{array}{l}.652 \\
.398\end{array}$ & -2.56 & 175 & .011 & -.343 & -.044 & 11.15 & .001 \\
\hline $\begin{array}{l}\text { I help colleagues to find value of } \\
\text { working as a teacher }\end{array}$ & $\begin{array}{l}\text { Higher performing } \\
\text { Lower performing }\end{array}$ & $\begin{array}{l}3.00 \\
3.01\end{array}$ & $\begin{array}{l}.367 \\
.399\end{array}$ & -.194 & 198 & .846 & -.117 & .096 & .448 & .504 \\
\hline $\begin{array}{l}\text { School team members challenge one } \\
\text { another to perform better }\end{array}$ & $\begin{array}{l}\text { Higher performing } \\
\text { Lower performing }\end{array}$ & $\begin{array}{l}2.85 \\
2.82\end{array}$ & $\begin{array}{l}.533 \\
.684\end{array}$ & .308 & 198 & .758 & -.144 & .197 & 3.148 & .078 \\
\hline
\end{tabular}

Higher performing school, $N=105$; Lower performing school, $N=95$

$* p<.05$ 


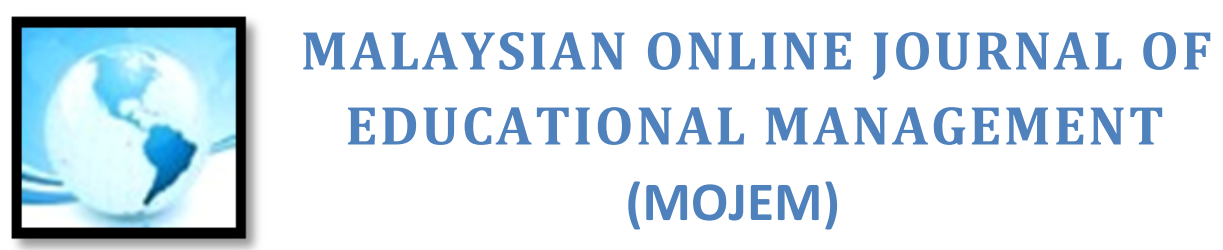

Result in Table 12 showed that there was only one item that indicates difference in terms of leadership in school. The result shows that there is significant difference between higher performing $(M=2.84, S D=.65)$ and lower performing $(M=3.03, S D=.40)$ school teachers' perception on the item "colleagues listen to my ideas because of my knowledge and skills", $t(175)=-2.56,0 p=.011$. The findings indicate lower performing school teachers highly perceive that their colleagues listen to their ideas.

\section{School level factors that determine students' performance in UPSR examinations}

To answer the second research question in this study, a multiple linear regression is used. Table 13 presented the result of multiple regression that was used to identify school level factors that determine students' performance in standard 6 examinations (UPSR examinations).

Table 13

Summary of Multiple Regression Analysis for UPSR GPS

\begin{tabular}{lccrrr}
\hline Variable & B & SE (B) & Beta & $t$ & \multicolumn{1}{c}{$\boldsymbol{t}$} \\
\hline Rural & -.098 & .065 & -.074 & -1.504 & .134 \\
Fully funded & $.190^{*}$ & .031 & .272 & 6.200 & .000 \\
Band & $.431^{*}$ & .035 & .610 & 12.284 & .000 \\
Number of teacher & $-.094^{*}$ & .047 & -.122 & -2.016 & .045 \\
Small class & $-.205^{*}$ & .060 & -.220 & -3.427 & .001 \\
Average parent income & $-.266^{*}$ & .055 & -.308 & -4.878 & .000 \\
Fund allocated & $.250^{*}$ & .056 & .335 & 4.430 & .000 \\
Experience & -.023 & .027 & -.032 & -.843 & .400 \\
Instructional materials & $.013^{*}$ & .005 & .111 & 2.367 & .019 \\
Science laboratory & $-.015^{*}$ & .005 & -.141 & -2.828 & .005 \\
Teacher shortage & $-.016^{*}$ & .005 & -.142 & -3.125 & .002 \\
Leadership in school & $.005^{*}$ & .005 & .114 & 2.741 & .007 \\
\hline$R^{2}=752$ & & & & &
\end{tabular}

Table 13 showed that fully funded schools are important factor that determines students' performance in UPSR exam. The coefficient is positive and statistically significant $(p<0.001)$. Similarly, the coefficient for Band is positive and statistically significant. This means that school band is an important factor that contributes to students' performance in UPSR examinations.

The coefficients for rural and teacher experience are not statistically significant. Thus, the location of the school and the experience of teacher are not considered as important factors that determine students' performance in UPSR examinations. In addition, the findings also indicate that the number of teachers is an important factor that determines students' performance in UPSR examinations, holding the other variables constant.

The coefficient for class size is negative and statistically significant. This means that when the class size decreases, the performance of students in UPSR examination will increase, holding other variables consistent. The coefficient of average income of students' parents is negative and statistically significant. Thus, socio-economic factor also influences students' performance in UPSR examinations.

The coefficient for fund is positive and statistically significant. Funding is an important factor that contributes to students' performance, holding other variables constant. The coefficient for instructional material is also positive and statistically significant. Thus, the result indicates that instructional materials are important determinant of students' performance in UPSR examinations. The result also shows that the coefficient for science laboratory is 


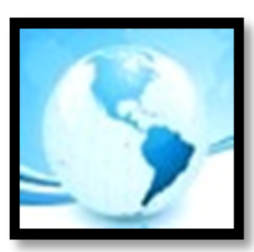

\section{MALAYSIAN ONLINE JOURNAL OF EDUCATIONAL MANAGEMENT (MOJEM)}

negative and statistically significant. This reflects that less adequate science laboratory in school or less equipment in science laboratory influences students' performance.

Result also showed that teachers' shortage is an important factor that determines students' performance in UPSR examination, holding the other variables constant. In addition, the coefficient for leadership is positive and statistically significant and mirrors the notion that leadership is an important factor that determines students' performance in UPSR examinations.

Overall, the findings indicated that there were certain school level resources that are important for students' performance in UPSR examinations. There were also significant differences in terms of school level resources between higher performing and lower performing schools. More funding and resources need to be provided to lower performing schools so that these schools would be able to provide quality education to students.

\section{IMPLICATIONS AND CONCLUSIONS}

The findings show that there are significant differences between higher performing and lower performing Chinese primary schools in terms of resources. Those resources are safe classrooms, availability of places to conduct discussion, the availability of latest books, having more than 2000 books, different types of books, enrichment books, high speed internet service in computer lab, the computer labs equipped with the latest software programs, the usage of VLE-frog to teach in classroom, latest model of computers in the classrooms, teacher classroom management, teacher shortage and colleagues listening to ideas. These findings provide insights that there are school level resource gaps between higher performing and lower performing schools. Having an equal opportunity in obtaining quality education is important to ensure that students in lower performing schools also obtain the same quality education. Quality education includes quality resources such as conducive learning environment, access to high speed computers, latest books in libraries and others. Thus, it is important for policy makers and school administrative to ensure that lower performing schools also have adequate resources to optimize learning.

The finding also indicated that school level factors that determine students' performance are funded school, band of school, number of teachers in school, small class, parent average income, fund allocated, instructional materials, science laboratory facilities, teacher shortage and leadership in school. Hanushek (2007) mentioned that the output of education is directly related to input of education. Class size showed significant effect on students' academic performance Students in small classroom could perform better than the larger classroom students. The smaller class students are able to increase their academic performance (Bruhwiler \& Blatchford, 2011; EnginDemir, 2009; Krishna, 2014; Malik Amer Atta et al., 2011). Thus, appropriate planning and interventions are needed at the ministry level to ensure that more teachers are trained to ensure smaller class. Small class size enables teachers to provide individualized attention to students.

Teachers experience was not significant in this research. Finding showed working experience of teachers didn't affect students' performance. However, Buddin and Zamarro (2009) found that teacher experience was able to increase students' performance but the linkage is weak for teachers who have one or two years teaching experience in school. In this research, instructional materials and science laboratory were part of the classroom resources that determined students' performance in UPSR examination. Further research needs to be conducted using various measures of teacher quality to see whether it is an important determinant of school performance.

Overall, the findings indicate that teachers perceive that there are significant differences between higher performing and lower performing schools in terms of school resources such as books, internet connections, teachers' leadership, classroom management. These findings provide insights to policy makers on the necessary policy interventions that need to be taken to ensure quality education regardless of the schools' performance. 


\section{REFERENCES}

Ahmad, H. (2012). Mission of public education in Malaysia: The challenge of transformation. Kuala Lumpur, Malaysia: University of Malaya Press.

Asún, R. A., Rdz-Navarro, K., \& Alvarado, J. M. (2016). Developing multidimensional Likert Scales using item factor analysis: The case of four-point items. Sociological Methods \& Research, 45(1), 109-133.

Blazar, D. (2015). Effective teaching in elementary mathematics: Identifying classroom practices that support student achievement. Economics of Education Review, 48, 16-29.

Bosworth, R. (2014). Class size, class composition, and the distribution of student achievement. Education Economics, 22(2), 141-165.

Bruhwiler, C., \& Blatchford, P. (2011). Effects of class size and adaptive teaching competency on classroom processes and academic outcome. Learning and Instruction, 21(1), 95-108.

Buddin, R., \& Zamarro, G. (2009). Teacher qualifications and student achievement in urban elementary schools. Journal of Urban Economics, 66(2), 103-115.

Chua, Y. P. (2013). Mastering Research Statistics. Selangor, Malaysia: McGraw-Hill Education.

Creswell, J. W. (2014). Research design: Qualitative, quantitative, and mixed methods approaches. Washington, DC: SAGE Publication.

Engin-Demir, C. (2009). Factors influencing the academic achievement of the Turkish urban poor. International Journal of Educational Development, 29(1), 17-29.

Fuje, H., \& Tandon, P. (2016). When do in-service teacher training and books improve student achievement? Experimental evidence from Mongolia (Doctoral dissertation). Retrieved from https://academiccommons.columbia.edu/doi/10.7916/D8N308KW/download

Galton, M., \& Pell, T. (2012). Longitudinal effects of class size reductions on attainment: Results from Hong Kong primary classrooms. International Journal of Educational Research, 53, 360-369.

Glewwe, P., \& Lambert, S. (2010). Education production functions: Evidence from developing countries. In P. Peterson, B. McGaw, \& E. Baker (Eds.), International Encyclopedia of Education (pp. 412-422). UK: Elsevier Ltd. https://doi.org/10.1016/B978-0-08-044894-7.01232-X

Hanushek, E. A. (1979). Conceptual and empirical issues in the estimation of educational production functions. Journal of Human Resources, 14(3), 351-388.

Hanushek, E. A. (2007). Education production functions. California, USA: Palgrave Encyclopedia.

Hanushek, E. A. (2010). Education production functions: Developed country evidence. International Encyclopedia of Education, 2, 407-411.

Harris, D. N., \& Sass, T. R. (2011). Teacher training, teacher quality and student achievement. Journal of Public Economics, 95(7-8), 798-812. 


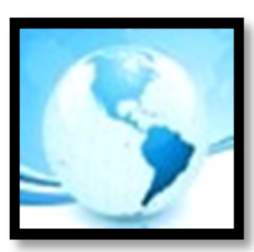

\section{MALAYSIAN ONLINE JOURNAL OF EDUCATIONAL MANAGEMENT (MOJEM)}

Jackson, E., \& Page, M. E. (2013). Estimating the distributional effects of education reforms: A look at Project STAR. Economics of Education Review, 32(2), 92-103.

Joseph, C. (2008). Ethnicities and education in Malaysia: Difference, inclusions and exclusions. In G. Wan (Ed.), The education of diverse student populations (pp. 183-208). Netherlands: Springer. Retrieved from http://www.springerlink.com/content/h1h8337724u45370/

Kenayathulla, H. B. (2014). Future trends in the management of school finance: A documentary analysis. Malaysian Online Journal of Educational Management (MOJEM), 2(4), 89-110.

Koc, N., \& Celik, B. (2015). The impact of number of students per teacher on student achievement. Procedia-Social and Behavioral Sciences, 177, $65-70$.

Krishna, P. P. (2014). Factors determining educational quality: Student Mathematics achievement in Nepal. International Journal of Educational Development, 34(1), 30-41.

Levačić, R., \& Vignoles, A. (2002). Researching the links between school resources and student outcomes in the UK: A review of issues and evidence. Education Economics, 10(3), 313-331.

Lounkaew, K. (2013). Explaining urban-rural differences in educational achievement in Thailand: Evidence from PISA literacy data. Economics of Education Review, 37, 213-225.

Low, S. F., \& Ishak, Z. (2012). Priori model of students' academic achievement: The effect of gender as moderator. International Congress on Interdisciplinary Business and Social Science, 65, 1092-1100.

Malik Amer Atta., Asif Jamil., Muhammad Ayaz., Tahir Shah., \& Muhammad Anwar Shah. (2011). Effect of the class size on the academic achievement of students at secondary school level. Interdisplinary Journal of Contemporary Research in Business, 3(2), 1592-1599.

Md Yunusa, M., Wan Osmana, W. S., \& Mohd Ishaka, N. (2011). Teacher-student relationship factor affecting motivation and academic achievement in ESL classroom. Procedia Social and Behavioral Sciences, 15(2011), 2637-2641.

Ministry of Education (MOE). (2012). Malaysia education blueprint 2013-2025. Retrieved from http://www.moe.gov.my/userfiles/file/PPP/Preliminary-Blueprint-Eng.pdf

Ministry of Education (MOE). (2015). Examination syndicate circular No. 2 Year 2015: Format for primary school assessment test (UPSR) Year 2016. Putrajaya, Malaysia: Examination Syndicate

Ministry of Education (MOE). (2016). Malaysian education statistics. Retrieved from: https://www.moe.gov.my/images/KPM/BPM/Media/Penerbitan/Terbitan/2017/Buku_Perangkaan_Pen didikan_Malaysia_2016/perangkaan2016_FINAL_intractive-1-page-001.jpg

Naoreen, B., Aslam, S., Arshad, M., \& Nausheen, R. (2011, October). Impact of in-service teacher training on students' learning achievement in mathematics. Paper presented at the International Conference on Social Science and Humanity, Singapore.

New York Comprehensive Center. (2011). Informational brief: Impact of school libraries on students achievement. Retrieved from http://www.nysl.nysed.gov/libdev/ nyla/nycc_school_library_brief.pdf

Newby, P. (2010). Research methods for education. UK, England: Pearson Education. 


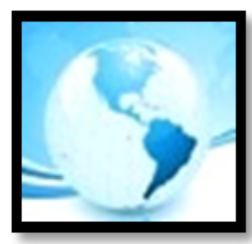

\section{MALAYSIAN ONLINE JOURNAL OF EDUCATIONAL MANAGEMENT \\ (MOJEM)}

Othman, M., \& Muijs, D. (2013). Educational quality differences in a middle-income country: the urban-rural gap in Malaysian primary schools. School Effectiveness and School Improvement, 24(1), 104-121.

Paola, M. D., Ponzo, M., \& Scoppa, V. (2013). Class size effects on student achievement: Heterogeneity across abilities and fields. Education Economics, 21(2), 135- 153.

Ping, D. (2008). Factors influencing students' adaptability in school. A production function model and multi-level analysis. Chinese Education and Society, 41(5), 21-35.

Polius, A. (2009). Low achievement in the primary school assessment test among rural student: Case study in Tenom, Sabah (Master's dissertation). Retrieved from http://eprints.ums.edu.my/9395/1/mt0000000441.pdf 